\title{
Akt/Protein Kinase B Prevents Injury-Induced Motoneuron Death and Accelerates Axonal Regeneration
}

\author{
Kazuhiko Namikawa, ${ }^{1}$ Masaru Honma, ${ }^{1,2}$ Koji Abe, ${ }^{1,3}$ Masumi Takeda,, ${ }^{1,4}$ Khalil Mansur, ${ }^{1}$ Tatsuo Obata, ${ }^{1}$ \\ Akiko Miwa, ${ }^{5,6}$ Haruo Okado, ${ }^{5,6}$ and Hiroshi Kiyama ${ }^{1,6}$
}

Departments of ${ }^{1}$ Anatomy, ${ }^{2}$ Dermatology, ${ }^{3}$ Psychiatry and Neurology, and ${ }^{4}$ Ophthalmology, Asahikawa Medical College, Asahikawa, Hokkaido, 078-8510 Japan, ${ }^{5}$ Department of Neurobiology, Tokyo Metropolitan Institute for Neuroscience, Fuchu, Tokyo, 183-8526 Japan, and ${ }^{6}$ Core Research for Evolutional Science and Technology (CREST), Japan Science and Technology, Kawaguchi, Saitama, 332-0012 Japan

\begin{abstract}
Motoneurons require neurotrophic factors for their survival and axonal projection during development, as well as nerve regeneration. By using the axotomy-induced neuronal death paradigm and adenovirus-mediated gene transfer, we attempted to gain insight into the functional significances of major growth factor receptor downstream cascades, Ras-extracellular signalregulated kinase (Ras-ERK) pathway and phosphatidylinositol-3 kinase-Akt (PI3K-Akt) pathway. After neonatal hypoglossal nerve transection, the constitutively active Akt-overexpressing neurons could survive as well as those overexpressing Bcl-2, whereas the constitutively active ERK kinase (MEK)-overexpressing ones
\end{abstract}

failed to survive. A dominant negative Akt experiment demonstrated that inhibition of Akt pathway hastened axotomy-induced neuronal death in the neonate. In addition, the dominant active Akt-overexpressing adult hypoglossal neurons showed accelerated axonal regeneration after axotomy. These results suggest that Akt plays dual roles in motoneuronal survival and nerve regeneration in vivo and that PI3K-Akt pathway is probably more vital in neuronal survival after injury than Ras-ERK pathway.

Key words: cell death; nerve injury; adenoviral gene transfer; hypoglossal; neuronal survival; nerve regeneration
An organized expression of various kinds of molecules would be essential for injured neurons to survive and regenerate (for review, see Persson and Ibáñez, 1993; Snider, 1994; Oppenheim, 1996; Pettmann and Henderson, 1998). In an attempt to explore the molecular basis of this process, we have used differential display-PCR to identify genes whose mRNA expression was upregulated in injured hypoglossal motoneurons and succeeded in isolating both novel and known molecules with possible association with neuronal survival and regeneration (Kiryu et al., 1995b; Morita et al., 1996; Su et al., 1997; Namikawa et al., 1998; Toki et al., 1998). In such gene screening studies, molecules restricted to certain intracellular signaling pathways were repeatedly hit. These are, for instance, Shc, 14-3-3, extracellular signalregulated kinase 1 (ERK1), ERK kinase 1 (MEK1), phosphatidylinositol-3 kinase (PI3K), and Akt (Kiryu et al., 1995a; Ito et al., 1996; Owada et al., 1997; Namikawa et al., 1998; Tanabe et al., 1998), which are molecules located downstream of growth factor receptor signaling pathways, in particular Ras-ERK and PI3KAkt cascades (for review, see Kaplan and Miller, 1997). The in

\footnotetext{
Received Oct. 19, 1999; revised Jan. 20, 2000; accepted Jan. 28, 2000.

This work was supported in part by Grant-in-Aid for Scientific Research from the Ministry of Education, Science, and Culture, Ministry of Heath and Welfare, and CREST. K.M. is a fellow of Ministry of Education, Science, and Culture Japan. We thank Drs. I. Saito and Y. Kanegae (University of Tokyo, Tokyo, Japan) for pAxCAwt, pAxCALNLw, AxCANLacZ, AxCALNLNZ, and AxCANCre; Dr. J. Miyazaki (Osaka University, Osaka, Japan) for CAG promoter in adenoviral vectors; Dr. S. J. Korsmeyer (Harvard Medical School, Boston, MA) for SSFV Bcl-2 expression plasmid; Drs. M. Kasuga and W. Ogawa (Kobe University, Kobe, Japan) for Akt-AA plasmid; and Drs. U. Kikkawa and H. Konishi (Kobe University) for anti-Akt antibody. We are grateful to Prof. U. Kikkawa for the critical reading of this manuscript, and T. Sasaki and K. Hazawa for technical assistance.

Correspondence should be addressed to Prof. Hiroshi Kiyama, Department of Anatomy, Asahikawa Medical College, 2-1-1-1, Midorigaokahigashi, Asahikawa, Hokkaido, 078-8510 Japan. E-mail: kiyama@asahikawa-med.ac.jp.

Copyright (C) 2000 Society for Neuroscience 0270-6474/00/202875-12\$15.00/0
}

vitro studies using culture cells have also indicated that these two pathways are vital for neuronal survival (for review, see Pettmann and Henderson, 1998). Currently, serine/threonine kinase Akt, also known as PKB (protein kinase B) or RAC-PK (related to A and C protein kinase) (Burgering and Coffer, 1995; Franke et al., 1995), has attracted much attention as a survival signal mediator, stimulated not only by growth factors but also by calcium influx (Dudek et al., 1997; Crowder and Freeman, 1998; Yano et al., 1998). Akt inactivates BAD, caspase-9, and FKHRL1 by phosphorylation and thereby blocks BAD-, caspase-9-, or FKHRL1induced cell death in vitro (Datta et al., 1997; del Peso et al., 1997, Cardone et al., 1998, Brunet et al., 1999). In addition to PI3K-Akt pathway, Ras-ERK pathway is another well established survival signaling pathway, at least in differentiated PC12 cells and Drosophila (Xia et al., 1995; Bergmann et al., 1998; Kurada and White, 1998). So far, both Ras-ERK and PI3K-Akt pathways have been considered to be the most vital for neuronal survival, and this fact strongly suggests some crucial roles of these pathways in injured motoneurons for their survival. However, the controversy remains as to whether they contribute equally to neuronal survival in vivo (in mammal). In the present study, we tried to address this issue by using axotomy-induced neuronal death paradigm (Hamburger, 1934; Romanes, 1946; Snider et al., 1992). Axotomy or the removal of peripheral targets in the neonate causes neuronal death, whereas axotomy in mature animals induces a regenerative response. In the present experimental paradigm, we attempted to gain insight into the functional significance of Ras-ERK and PI3K-Akt pathways by using adenovirus vectors (Akli et al., 1993; Davidson et al., 1993), carrying recombinant genes for the pivotal molecules to actively manipulate these cascades in specific ways, in injured motoneurons of neonate rats. Here, we have revealed distinct functional differences 
between these two signaling pathways. In addition, we have also revealed a novel activity of Akt on neurite elongation both in vitro and in vivo.

\section{MATERIALS AND METHODS}

Animals and surgery. The hypoglossal nerve was cut unilaterally in both neonate (3-d-old) and adult (6-week-old) Wistar rats. Briefly, rats were anesthetized with pentobarbital and positioned supine, and the unilateral hypoglossal nerve was cut with a pair of scissors.

In situ hybridization and immunohistochemistry. In situ hybridization on brain sections was performed using digoxigenin (DIG)-UTP-labeled cRNA probe. For Akt mRNA detection, a cDNA (1147-1610) fragment of rat Akt1 (Konishi et al., 1994) was isolated from rat whole brain cDNA by using PCR. Hybridization were performed on fresh frozen sections $(18 \mu \mathrm{m})$ of neonatal rats $3 \mathrm{~d}$ after axotomy or adult rats $7 \mathrm{~d}$ after axotomy. Briefly, the sections were prehybridized and then hybridized at $58^{\circ} \mathrm{C}$ for $16 \mathrm{hr}$ in hybridization buffer [50\% deionized formamide, $0.3 \mathrm{M}$ $\mathrm{NaCl}, 20 \mathrm{~mm}$ EDTA, $10 \mathrm{~mm}$ phosphate buffer (PB), 10\% dextran sulfate, $1 \times$ Denhardt's solution, $0.2 \%$ sarcosyl, $500 \mu \mathrm{g} / \mathrm{ml}$ yeast tRNA, and 200 $\mu \mathrm{g} / \mathrm{ml}$ denatured salmon sperm DNA] containing $40 \mathrm{ng} / \mu \mathrm{l}$ DIG-labeled RNA probe. After hybridization, washing was performed twice at $65^{\circ} \mathrm{C}$ in $50 \%$ formamide and $2 \times \mathrm{SSC}$ for each $30 \mathrm{~min}$. The signal was detected by using the DIG nucleic acid detection kit (Boehringer Mannheim, Indianapolis, IN) according to the manufacturer's protocol. Immunohistochemical studies on brain sections were performed as described previously (Kiryu et al., 1995a). Neonate rats $3 \mathrm{~d}$ after axotomy or adult rats $7 \mathrm{~d}$ after axotomy were fixed in Zamboni's fixative $(0.1 \mathrm{M}$ PB containing $2 \%$ paraformaldehyde and $0.2 \%$ picric acid), and brains were cryoprotected in $20 \%$ sucrose and then sectioned $(20 \mu \mathrm{m})$. Anti-phospho Akt polyclonal antibody (1:300; New England Biolabs, Beverly, MA) specific to phosphorylated Akt at $\operatorname{Ser}^{473}$ was used.

Construction of adenoviral vectors. Recombinant adenoviral vectors were constructed in the following manner. The cDNA fragments comprising the entire coding regions for human MEK1 and human Akt1, were isolated from human embryonic kidney 293 (HEK293) cDNA by using PCR. Constitutively active MEK, which lacks its nuclear export signal (Fukuda et al., 1997) (amino acid 32-51) and which has the substitution of glutamic acid for two phosphorylation sites, $\operatorname{Ser}^{218}$ and $\mathrm{Ser}^{222}$, were prepared by site-directed mutagenesis as described previously (Mansour et al., 1994). After that, c-Myc tag sequence was fused to its $\mathrm{N}$ terminal by using PCR. Constitutively active Akt, which lacks its pleckstrin homology domain (amino acid 4-129) but has srcmyristoylation signal sequence (MGSSKSKPKDPSQRR) (Resh, 1994) fused to its $\mathrm{N}$-terminal end and hemagglutinin epitope tag (HA tag) to its C-terminal end (Kohn et al., 1996a), was also prepared by using PCR. Akt-AA (rat Akt1 T308A/S473A), which also contains HA tag in its $\mathrm{N}$ terminal and works as dominant negative mutant of Akt (Kitamura et al., 1998), was kindly provided by Drs. M. Kasuga and W. Ogawa (Kobe University, Kobe, Japan). Bcl-2 expression plasmid SSFV Bcl-2, carrying the entire coding sequence of human Bcl-2, was kindly provided by Dr. S. J. Korsmeyer (Harvard Medical School, Boston, MA). da-MEK was subcloned into pAxCAwt (Miyake et al., 1996), an expression cosmid cassette, which was created from the human type 5 adenovirus genome from which the E1A, E1B, and E3 regions were deleted and which replaced the expression unit under the control of CAG promoter (Niwa et al., 1991) On the other hand, the fragments of myr-Akt, Akt-AA and $\mathrm{Bcl}-2$ were subcloned into pAxCALNLw Cre-lox P system mediated expression cassette (Sato et al., 1998a) as described below. The recombinant adenovirus vectors AxCAda-MEK, AxCALNLmyr-Akt, AxCALNLAkt-AA, and AxCALNLBcl-2 were constructed by the COS-terminal protein complex (TPC) method (Miyake et al., 1996). Each expression cosmid cassette and EcoT22I digested adenovirus DNA-TPC (Ad5dlX DNA-TPC) were cotransfected into HEK293 cells, and the recombinant adenoviruses were generated by homologous recombination and amplified in HEK293 cells. Finally, high titered recombinant viral stocks were generated in HEK293 cells, purified by cesium gradient centrifugation (Kanegae et al., 1994), and stored at $-80^{\circ} \mathrm{C}$ until use. The viral titers were determined by plaque-forming assay in HEK293 cells. AxCANLacZ (Terashima et al., 1997), AxCALNLNZ (Sato et al., 1998a), and AxCANCre (Kanegae et al., 1995) were kindly provided by Drs. I. Saito and Y. Kanegae (University of Tokyo, Tokyo, Japan).

Cell culture. PC12 cells were maintained in RPMI 1640 medium containing $5 \%$ fetal bovine serum and $10 \%$ heat-inactivated horse serum. The cells were differentiated for $9-10 \mathrm{~d}$ in the same medium containing
$0.5 \%$ fetal bovine serum and nerve growth factor (NGF) $(50 \mathrm{ng} / \mathrm{ml}$; Promega, Madison, WI).

Western blotting. Western blotting was done according to the following procedure. Protein $(20 \mu \mathrm{g})$ from adenoviral-infected whole-cell extracts (the infections were performed as the described below) were separated by SDS-PAGE, and blots were prepared on polyvinylidene difluoride membranes (Bio-Rad, Richmond, CA). The following primary antibodies were used as probes: for myr-Akt, anti-phospho Akt polyclonal antibody (1:1000; New England Biolabs) and anti-HA monoclonal antibody (12CA5) (1:2000; Boehringer Mannheim); for Akt-AA, anti-Akt polyclonal antibody (Kitamura et al., 1998) (kindly provided by Drs. U. Kikkawa and H. Konishi) and anti-HA monoclonal antibody (12CA5); for da-MEK, anti-c-Myc monoclonal antibody (9E10); for phosphorylation of ERKs, anti-phospho ERK polyclonal antibody (1:1000; New England Biolabs); for Bcl-2, anti-Bcl-2 polyclonal antibody (1:1000; Santa Cruz Biotechnology, Santa Cruz, CA); and for phosphorylation of c-Jun N-terminal protein kinases (JNKs) or p38, anti-phospho JNK polyclonal antibody (1:1000; New England Biolabs) or anti-phospho p38 polyclonal antibody (1:1000; New England Biolabs), respectively. Blots were then probed with horseradish peroxidase-conjugated goat anti-mouse or antirabbit secondary antibody (Amersham, Arlington Heights, IL) and visualized by using chemiluminescence system (ECL; Amersham)

In vitro kinase assay. To detect the activity of adenovirus-expressed myr-Akt or Akt-AA under the presence or absence of NGF $(100 \mathrm{ng} / \mathrm{ml}$; 3 min after stimulation), we lysed the cells $36 \mathrm{hr}$ after the infection in a solution containing $20 \mathrm{~mm}$ Tris- $\mathrm{HCl}$ at $\mathrm{pH} 7.5,1 \mathrm{~mm}$ EDTA, $1 \mathrm{~mm}$ EGTA, $10 \mathrm{~mm}$ 2-mercaptoethanol, 1\% Triton X-100, $150 \mathrm{~mm} \mathrm{NaCl}$, $10 \mathrm{~mm} \mathrm{NaF}, 1 \mathrm{~mm} \mathrm{Na} \mathrm{VO}_{4}$, and $25 \mathrm{~mm}$ phenylmethylsulfonyl fluoride. The lysates were immunoprecipitated with protein A-Sepharose (Pharmacia, Uppsala, Sweden) coupled with anti-HA polyclonal antibody (1:100; Santa Cruz Biotechnology) for $3 \mathrm{hr}$ at $4^{\circ} \mathrm{C}$. After washing three times in $20 \mathrm{~mm}$ Tris- $\mathrm{HCl}$ at $\mathrm{pH} 7.5$ containing $150 \mathrm{~mm} \mathrm{NaCl}$ and $1 \%$ Triton $\mathrm{X}-100$, the final immunoprecipitates were incubated for $30 \mathrm{~min}$ at $30^{\circ} \mathrm{C}$ in a reaction buffer $(25 \mu \mathrm{l})$ containing $20 \mathrm{~mm}$ Tris- $\mathrm{HCl}$ at $\mathrm{pH} 7.5$, $10 \mathrm{~mm} \mathrm{MgCl}_{2}, 20 \mu \mathrm{M}$ cold ATP, $50 \mathrm{kBq} \gamma^{-32} \mathrm{P}$ ATP (DuPont NEN, Boston, MA), $1 \mathrm{~mm}$ protein kinase inhibitor (Sigma, St. Louis, MO), and $5 \mu \mathrm{g}$ of histone $\mathrm{H} 2 \mathrm{~B}$ (Boehringer Mannheim) or $3 \mu \mathrm{g}$ of glutathione $S$-transferase (GST)-BAD fusion protein as substrates. The reactions were terminated by adding SDS-PAGE sample buffer to the supernatants and analyzed by $10 \%$ (for visualization of GST-BAD) or $15 \%$ (for visualization of histone H2B) SDS-PAGE, followed by autoradiography. The same immunoprecipitations were also used for Western blot analysis with anti-Akt antibody. On the other hand, dominant negative effect of Akt-AA was estimated by measuring endogenous Akt activity in Akt-AA-overexpressing PC12 cells. In this study, LY294002 (Sigma) was added into some dishes at the concentration of $100 \mu \mathrm{M} 15 \mathrm{~min}$ before NGF stimulation. The lysates were subjected to three sequential immunoprecipitations with anti-HA polyclonal antibody (1:100; Santa Cruz Biotechnology) for $90 \mathrm{~min}$ to remove adenovirus-expressed Akt-AA. The final supernatants were then subjected to immunoprecipitation with polyclonal antibody to Akt, and Akt kinase assay with the resulting immunoprecipitates and Western blot analysis using anti-Akt antibody were performed as described above.

Immunostaining and survival assays using adenoviral expression in differentiated PC12 cells. To estimate the survival activity of each virus, neuronally differentiated PC12 cells were infected with AxCANLacZ [multiplicity of infection (MOI) 100], AxCAda-MEK (MOI 100), AxCALNLmyr-Akt plus AxCANCre (MOI 100/30), or AxCALNLBcl-2 plus AxCANCre (MOI 100/30) and then maintained in NGF-containing $(50 \mathrm{ng} / \mathrm{ml})$ medium. Thirty-six hours later, cells were washed two times with NGF-free medium followed by incubation in NGF-free medium containing neutralizing antibody to $2.5 \mathrm{~S}$ NGF (Sigma) at a 1:1000 dilution. Then, $18 \mathrm{hr}$ later, immunocytochemistry was done to detect $\beta$-galactosidase $(\beta$-Gal) or myr-Akt-expressing cells, using the anti- $\beta$ Gal polyclonal antibody (1:500; Organon Teknika, West Chester, PA) or the anti-HA polyclonal antibody (1:300; Santa Cruz Biotechnology), respectively. FITC-conjugated antibody (Vector Laboratories, Burlingame, CA) was used as the secondary antibody. Subsequently, Hoechst staining was done (Hoechst 33258, $2.5 \mu \mathrm{g} / \mathrm{ml}$; Wako, Tokyo, Japan) to visualize their nuclei. For cell viability assay, quantitative determinations of surviving cells were done 0,24 , or $48 \mathrm{hr}$ after NGF withdrawal. The biochemical method using a highly water-soluble tetrazolium salt (WST1), neutral red and crystal violet (Ishiyama et al., 1996), was used to determine the percent ratio of surviving cells following the manufacturer's protocol (Nakalai Tesque, Kyoto, Japan). On the other hand, to 

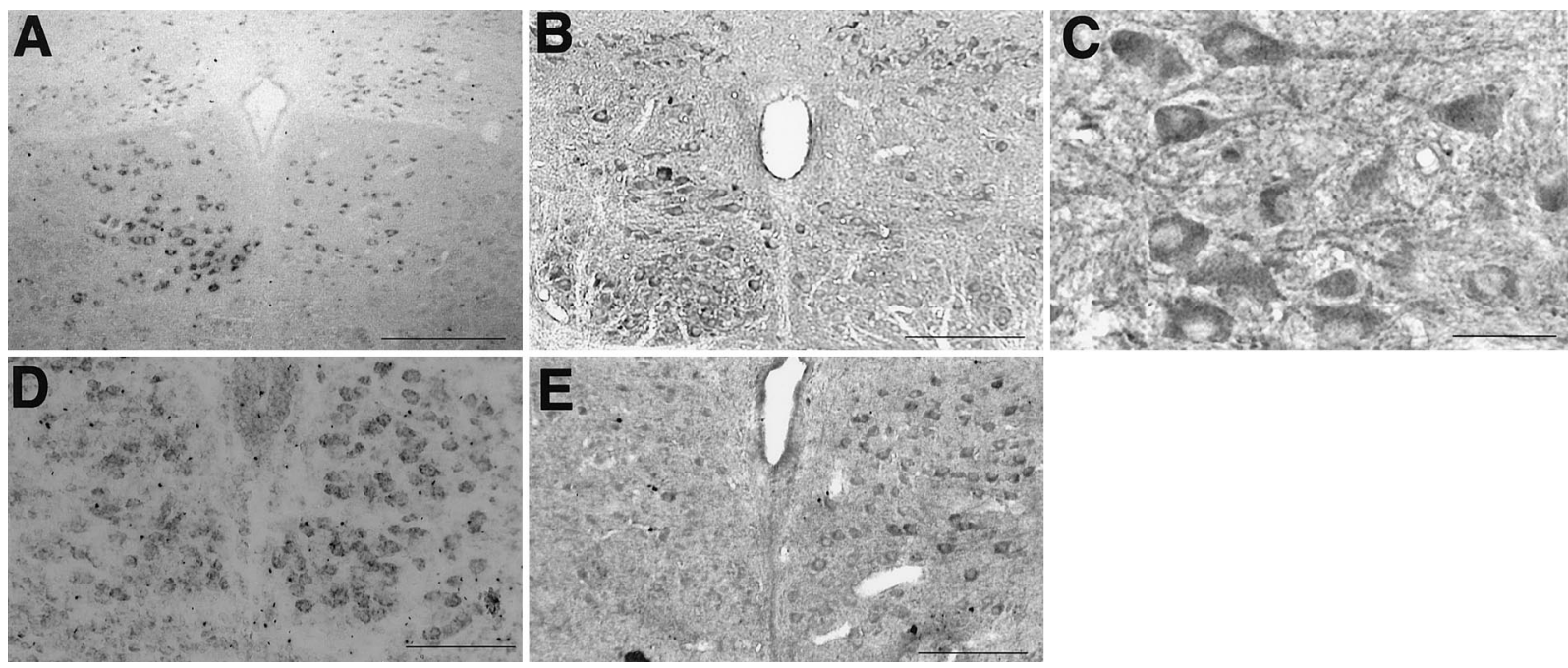

Figure 1. Expression and activation of Akt in injured hypoglossal motoneurons are oppositely regulated between neonate and adult. $A$, Expression of Akt1 mRNA demonstrated by in situ hybridization using DIG-labeled Akt1 antisense RNA probe. Photograph indicates markedly upregulated signal in injured hypoglossal motoneurons (left) of adult rat $7 \mathrm{~d}$ after axotomy. $B, C$, Immunohistochemical demonstrations of phosphorylated Akt at Ser ${ }^{473}$ (P-Akt). B, In the adult rat, enhanced P-Akt expression was observed in injured hypoglossal nucleus (left) compared with the control hypoglossal nucleus (right) $7 \mathrm{~d}$ after axotomy. $C$, High-power magnification indicates that most of the injured motoneurons show intense P-Akt immunoreactivity. $D$, $E$, Decreased Akt expression and activity in the neonate injured motoneurons in response to axotomy. $D$, Expression of Akt1 mRNA was downregulated on the injured side (left) $3 \mathrm{~d}$ after axotomy. $E$, Immunohistochemistry also showed few P-Akt-positive neurons in the injured side (left), whereas many immunostained motoneurons are observed on control side (right) $3 \mathrm{~d}$ after axotomy. Scale bars: $A, 600 \mu \mathrm{m} ; B, 500 \mu \mathrm{m} ; C, 50 \mu \mathrm{m} ; D, E, 200 \mu \mathrm{m}$.

evaluate the pro-apoptotic ability of Akt-AA under the presence of NGF, differentiated PC12 cells were infected with AxCALNLAkt-AA plus AxCANCre (MOI 100/30) or AxCALNLNZ plus AxCANCre (MOI 100/30). Twenty-four hours after infection, virus-infected cells were stained as described above. Cell viability assay was done after $0,24,48$, and $72 \mathrm{hr}$ after the virus infection under the presence of NGF using the same method described above. In addition, the effect of LY294002 (100 $\mu \mathrm{M})$ on the same cells was also estimated 0,24 , and $48 \mathrm{hr}$ after the treatment.

Effects of the adenoviral infection on rat neonatal hypoglossal motoneurons after axotomy. AxCANLacZ $\left(1.7 \times 10^{8} \mathrm{pfu} / 5 \mu \mathrm{l}\right)$, AxCAda-MEK $\left(1.0 \times 10^{8} \mathrm{pfu} / 5 \mu \mathrm{l}\right)$, AxCALNLmyr-Akt plus AxCANCre $\left(1.3 \times 10^{8}\right.$ pfu/5 $\mu \mathrm{l}$ and $1.9 \times 10^{7} \mathrm{pfu} / 5 \mu \mathrm{l}$, respectively), AxCALNLBcl-2 plus AxCANCre $\left(3.3 \times 10^{7} \mathrm{pfu} / 5 \mu \mathrm{l}\right.$ and $1.9 \times 10^{7} / 5 \mu \mathrm{l}$, respectively $)$, AxCALNLAkt-AA plus AxCANCre $\left(1.8 \times 10^{8} \mathrm{pfu} / 5 \mu \mathrm{l}\right.$ and $1.9 \times 10^{7}$ pfu $/ 5 \mu$ l, respectively), or AxCALNLNZ plus AxCANCre $\left(3.3 \times 10^{8}\right.$ pfu/5 $\mu \mathrm{l}$ and $1.9 \times 10^{7} \mathrm{pfu} / 5 \mu \mathrm{l}$, respectively) was injected unilaterally into tongues of neonatal rats (1-d-old). Efficiency of viral infection was assessed by 5 -bromo-4-chloro-3-indolyl- $\beta$-D-galactopyranoside (X-Gal) histochemistry (Terashima et al., 1997), counterstained with neutral red, using the brainstem sections of AxCANLacZ-infected nonoperated animals. Two days after injection of each virus, pups were operated (3-dold). For evaluation of survival activity by da-MEK-, myr-Akt-, Bcl-2-, and LacZ-expressing virus, the infected animals were perfused transcardially with $4 \%$ paraformaldehyde in $0.1 \mathrm{M}$ PB on postaxotomy day 12 . On the other hand, for evaluation of death-promoting activity by Akt-AA, the rats infected with AxCALNLAkt-AA plus AxCANCre were decapitated at $36 \mathrm{hr}$ or 3, 5, or $7 \mathrm{~d}$ after axotomy. In this study, AxCALNLNZ and AxCANCre were used as a control viruses. Sections $(20 \mu \mathrm{m})$ were taken through hypoglossal nuclei region and stained with thionin, and neurons were counted on both operated and control sides. Survival effects of recombinant viral infections were determined by calculating the percent ratio of the surviving motoneurons in the operated side compared with those on control side. In some experiments, the sections were processed for immunohistochemistry as described above. To identify recombinant adenoviral-infected neurons, anti-c-Myc antibody (9E10) or anti-HA polyclonal antibody (1:300; Santa Cruz Biotechnology) was used for the detection of c-Myc-tagged da-MEK, HA-tagged myr-Akt, or HA-tagged Akt-AA, respectively, followed by thionin staining.

Death-promoting assay of Akt-AA adenovirus in the adult rat hypoglossal motoneurons after axotomy. AxCALNLNZ plus AxCANCre $\left(3.3 \times 10^{8}\right.$ $\mathrm{pfu} / 5 \mu \mathrm{l}$ and $1.9 \times 10^{7} \mathrm{pfu} / 5 \mu \mathrm{l}$, respectively) or AxCALNLAkt-AA plus AxCANCre $\left(1.8 \times 10^{8} \mathrm{pfu} / 5 \mu \mathrm{l}\right.$ and $1.9 \times 10^{7} \mathrm{pfu} / 5 \mu \mathrm{l}$, respec- tively) was infected through the cut axon tips immediately after the transection of unilateral hypoglossal nerve in adult rats. Animals were killed at 6,10 , or $14 \mathrm{~d}$ after axotomy, and the methods for preparations of brain sections and the calculation of percent survival ratio of injured motoneurons were performed as described above.

Infection of myr-Akt-expressing adenovirus into undifferentiated PC12 cells. AxCANLacZ (MOI 100) or AxCALNLmyr-Akt plus AxCANCre (MOI 100/30) was infected into undifferentiated PC12 cells. For immunostaining, cells were fixed $2 \mathrm{~d}$ after the infection and stained as described above. For an estimation of neurite outgrowth, the number of cells whose neurites are longer than their cell bodies was counted, and the percent ratio of the number of neurite bearing cells was calculated. (Four different experiments were performed for each value.)

In vivo assay for nerve regeneration. AxCANLacZ $\left(1.7 \times 10^{8} \mathrm{pfu} / 5 \mu \mathrm{l}\right)$ or AxCALNLmyr-Akt plus AxCANCre $\left(1.3 \times 10^{8} \mathrm{pfu} / 5 \mu \mathrm{l}\right.$ or $1.9 \times 10^{7}$ $\mathrm{pfu} / 5 \mu \mathrm{l}$, respectively) was infected into injured motoneurons in adult rats as described above. One week later, immunohistochemistry was done with the brainstem sections for detection of $\beta$-Gal-positive neurons or HA-positive myr-Akt-expressing neurons as described above. Nerve regeneration was assessed by using the retrograde tracer Fluoro-Gold (FG) (Fluorochrom Inc., Englewood, CO), 2, 3, and 4 weeks after axotomy as described previously (Hirota et al., 1996).

\section{RESULTS}

\section{Akt activation in response to nerve injury is oppositely regulated between newborn and adult}

In adult injured motoneurons, upregulated expressions of the ligands (neurotrophic factors), the receptors, and the intracellular signaling molecules have been proved; however, these responses in neonate have not been so well characterized yet. If the activation of Akt is observed in the neonate paradigm in which the injured neuron is fated to die, Akt may not be the crucial molecule in survival. Therefore, before addressing the main issue, we examined the possibility of differences in Akt response after axotomy in neonate and adult hypoglossal motoneurons. After hypoglossal nerve axotomy, Akt1 mRNA (Fig. 1A) was markedly upregulated in injured hypoglossal neurons in adult rat. For activation of Akt, the phosphorylation of Akt1 at serine 473 $\left(\mathrm{Ser}^{473}\right)$ after the phosphorylation of threonine $308\left(\mathrm{Thr}^{308}\right)$ is 
necessary through the growth factor receptor stimulation (for review, see Downward, 1998). Immunohistochemistry using an antibody specific to phosphorylated Akt at $\operatorname{Ser}^{473}$ revealed that phosphorylated Akt protein dramatically increased in injured adult motoneurons (surviving after axotomy) (Fig. 1B,C), whereas the expression of Akt1 mRNA and phosphorylated Akt decreased after axotomy in injured neonate motoneurons (Fig. 1D,E). Thus, injured neonate motoneurons that were destined to die somehow failed to upregulate and phosphorylate Akt in response to nerve injury.

\section{Construction of adenoviral vectors and their activity}

To activate two different pathways in injured motoneurons, we attempted to use a dominant active form of Akt (for activation of PI3K-Akt pathway) or MEK (for activation of Ras-ERK pathway). A dominant negative form of Akt was also prepared to inhibit the Akt signaling cascade in a specific manner. In addition, Bcl-2, a well known molecule that promotes motoneuron survival after axotomy as described previously (Farlie et al., 1995), was also used for the quantitative analysis of the efficacy of our experimental paradigm. By using adenovirus vectors, we constructed four recombinant genes, namely, HA-tagged constitutively active Akt [myristoylated Akt1(myr-Akt): $\Delta 4-129$, designated AxCALNLmyr-Akt] (Kohn et al., 1996b), HA-tagged dominant negative Akt [Akt1 T308A/S473A (Akt-AA), designated AxCALNLAkt-AA] (Kitamura et al., 1998), c-Myc-tagged constitutively active MEK [dominant active MEK1(da-MEK): $\Delta 32-51$; S218E/S222E, designated AxCAda-MEK] (Mansour et al., 1994), and Bcl-2 (designated AxCALNLBcl-2).

By using an ordinary procedure (see Materials and Methods), we failed to obtain recombinant viruses expressing myr-Akt and Bcl-2. In addition, although we succeeded in getting Akt-AArepresenting adenovirus, it could not become a high-titered one $\left(<10^{10} \mathrm{pfu} / \mathrm{ml}\right)$ and was not effective enough to be used in animal experiments. We concluded that very high expression of these recombinant molecules under the control of the CAG promoter (composed of the cytomegalovirus enhancer plus the chicken $\beta$-actin promoter, and the rabbit $\beta$-globin polyadenylation signal sequence), might be producing some deleterious effects in their amplification in HEK293 cells. Consequently, these three gene sequences were inserted into a novel type of adenoviral vector, which bears an ON-OFF switching unit for activation by Cre recombinase (Sato et al., 1998a,b). The switching unit in the vector contained a stuffer sequence encoding Neo with a functional polyadenylation signal between the promoter and the inserted cDNA fragment, thereby blocking its expression during viral amplification in HEK293 cells. The stuffer is flanked by a pair of loxP sites, allowing its excision by Cre leading to expression of the inserted cDNA sequence. To obtain the expression of myr-Akt, Akt-AA, or Bcl-2, we performed coinfection of the nuclear localization signal (NLS)-tagged Cre recombinase expressing virus (AxCANCre) (Kanegae et al., 1995) plus AxCALNLmyr-Akt, AxCANCre plus AxCALNLAkt-AA or AxCANCre plus AxCALNLBcl-2, respectively. The NLS-LacZ virus (AxCANLacZ) or Cre-mediated NLS-LacZ virus (AxCALNLNZ) (Terashima et al., 1997; Sato et al., 1998a) were used as control vectors.

The expression and efficiency of these recombinant viruses were examined in PC12 cells. The expression of HA-tagged myr-Akt (as detected by anti-phospho Akt at $\operatorname{Ser}^{473}$ or anti-HA antibody) and Akt-AA (as detected by anti-Akt antibody or anti-HA antibody) were observed only when they were coinfected with AxCANCre (Fig. 2A,B). The functional efficacy of the expressed myr-Akt and Akt-AA were assessed by phosphorylation of substrates, such as histone $\mathrm{H} 2 \mathrm{~B}$ and recombinant BAD protein, in vitro. Although myr-Akt expressed by adenovirus had a vital activity under both the absence and presence of NGF, Akt-AA completely lost its activity, even after NGF stimulation (Fig. 2C). In addition, overexpression of Akt-AA could succeed in decreasing the endogenous Akt activity in NGF-stimulated PC12 cells with a similar efficacy as the PI3K inhibitor LY294002 (Fig. 2D). The expressed c-Myc-tagged da-MEK (as detected by anti-c-Myc antibody) was also effective in phosphorylating ERK1 and ERK2 (as detected by anti-phospho ERK antibody) (Fig. 2E). Furthermore, the expression of Bcl-2 was observed only when both AxCALNLBcl-2 and AxCANCre were coinfected (as detected by anti-Bcl-2 antibody) (Fig. $2 F$ ).

\section{Survival activities of the recombinant viruses in differentiated PC12 cells}

Survival activities of myr-Akt-, da-MEK-, and Bcl-2-expressing recombinant adenoviruses were evaluated in differentiated PC12 cells, because the previous studies demonstrated that these molecules are survival inducers in PC12 cells and/or sympathetic primary neurons after NGF withdrawal (Batistatou et al., 1993; Xia et al., 1995; Philpott et al., 1997; Crowder and Freeman, 1998). Before NGF deprivation, these adenoviruses were infected into the differentiated cells. Then the medium was changed to NGF-free medium. The Hoechst staining (Hoechst 33258) readily demonstrated apoptotic profiles in the dying cells infected with LacZ-expressing virus (Fig. $3 A$ ), and more than half of the virus infected cells died within $24 \mathrm{hr}$ (Fig. 3B). On the other hand, cells infected with myr-Akt, da-MEK, and Bcl-2 carrying recombinant adenoviruses showed almost no signs of any physical deterioration (Fig. 3B). Furthermore, Hoechst staining also showed no apoptotic profiles in myr-Akt-overexpressing cells (Fig. 3A). These observations indicated that adenoviral expression of both myr-Akt and da-MEK had similar efficacies equivalent to that of Bcl-2 in survival of NGF-deprived PC12 cells.

A dominant negative effect by Akt-AA-expressing virus was also evaluated in $\mathrm{PC} 12$ cells with NGF. The cells infected AxCALNLNZ plus AxCANCre were not represented apoptotic profiles under the presence of NGF, but Akt-AA-overexpressed cells did show shrunken cell soma, fragmented neurite, and condensed chromatin in their nuclei similar to NGF-deprived cells (Fig. 3C). The survival ratios of the cells after the infection of Akt-AA virus and that of the cells treated with LY294002 $(100 \mu \mathrm{M})$ decreased substantially with the passage of time (Fig. 3D). The results indicated that activation of PI3K-Akt pathway is necessary for survival of NGF-dependent PC12 cells.

\section{Akt, but not MEK, can prevent axotomy-induced neuronal death}

To further clarify the roles of PI3K-Akt and Ras-ERK pathways in the prevention of axotomy-induced neuronal death in vivo, these recombinant adenoviruses were injected into the tongues of neonate rats (1-d-old) to allow retrograde infection into the hypoglossal motoneurons. The efficacy of this method was preliminarily verified in neonate rat pups using AxCANLacZ. When AxCANLacZ was injected into unilateral sides of tongues of neonates, $>20 \%$ of ipsilateral hypoglossal motoneurons were labeled as $\beta$-Gal-positive (Fig. 4A). Two days after injection, ipsilateral hypoglossal nerve was axotomized (on postnatal day 3). Adenoviral expressions of myr-Akt and da-MEK in injured motoneurons were observed immunohistochemically by using 

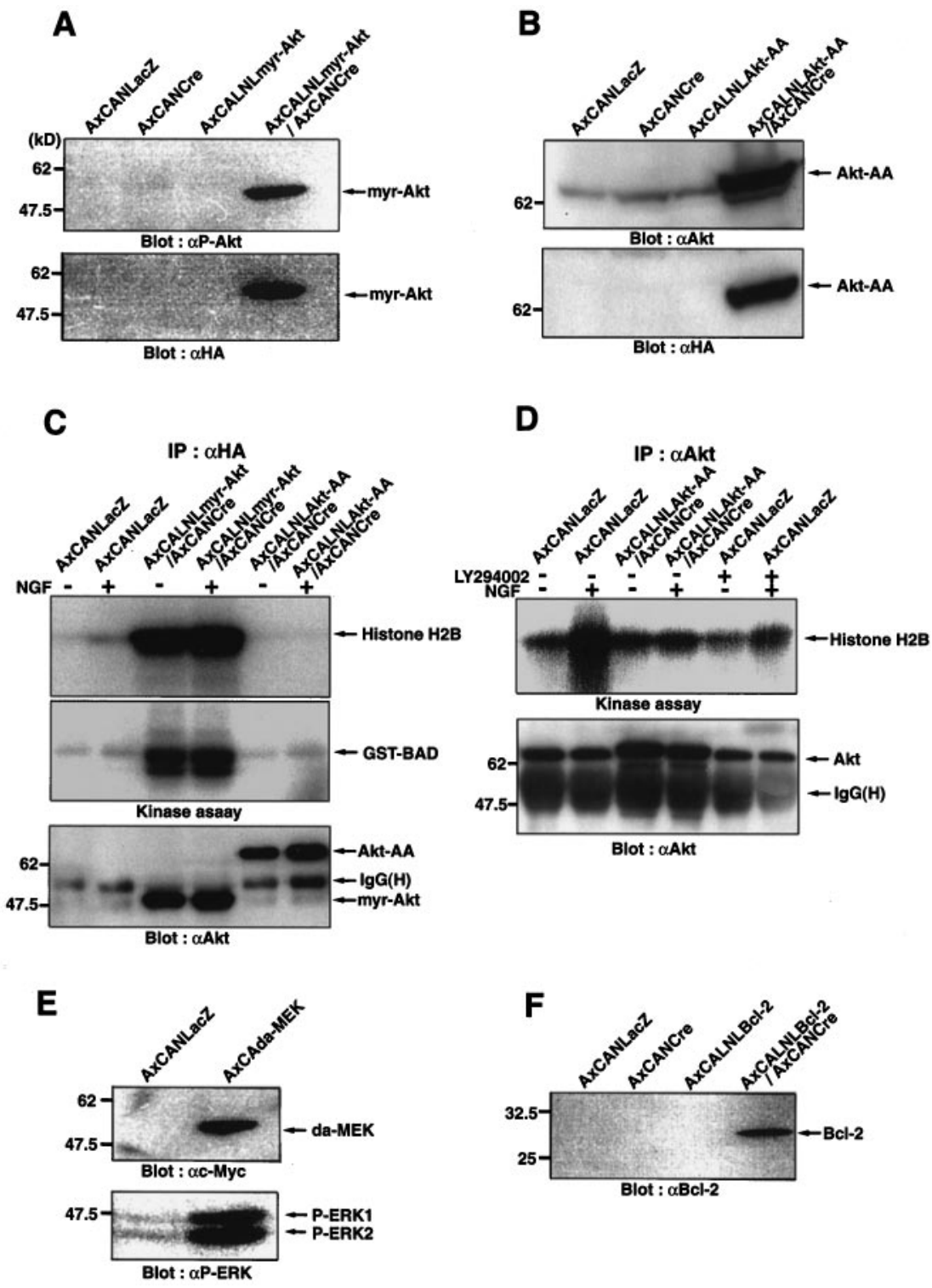

Figure 2. Expression and activity of myr-Akt, Akt-AA, da-MEK, and Bcl-2 in PC12 cells by recombinant adenoviral gene transfer. These cells were lysed $36 \mathrm{hr}$ after viral infection. $A$, Expression of HA-tagged myr-Akt, which is demonstrated by anti-P-Akt or anti-HA antibody, is found only in the case of the double infection with AxCALNLmyr-Akt and AxCANCre. $B$, Expression of HA-tagged Akt-AA was also detected by antiAkt or anti-HA antibody only when the double infection (AxCALNLAkt-AA plus AxCANCre) was performed. $C$, LacZ-, myr-Akt-, or Akt-AA-expressing virus was infected into the cells and lysed ( $36 \mathrm{hr}$ after infection) under the presence ( $100 \mathrm{ng} / \mathrm{ml} ; 3$ min after stimulation) or absence of NGF. Thereafter, these lysates were immunoprecipitated with anti-HA polyclonal antibody (IP: $\alpha H A$ ), and the kinase activity of myr-Akt or Akt-AA was examined with phosphorylation of substrates such as histone $\mathrm{H} 2 \mathrm{~B}$ and recombinant BAD. The same immunoprecipitations were also used for Western blot analysis with anti-Akt antibody to confirm the expression. Note that the adenovirus-expressed myr-Akt showed strong phosphorylation activity, whereas Akt-AA completely lost the phosphorylation activity, even under the existence of NGF. D, Adenovirus-expressed Akt-AA could reduce endogenous Akt activity at a similar level to LY294002 treatment $(100 \mu \mathrm{M})$, even after NGF stimulation. Akt kinase assay was performed after the immunoprecipitation with anti-Akt polyclonal antibody (IP: $\alpha A k t)$. E, Expression of c-Myc-tagged da-MEK in PC12 cells was detected by anti-c-Myc antibody. The da-MEK expression also induced phosphorylation of ERKs (ERK1 and ERK2) in the same cells, which were detected by anti-phospho ERK antibody. $F$, Expression of $\mathrm{Bcl}-2$ in PC12 cells was observed (detected by antiBcl-2 antibody) only in the case of the double infection (AxCALNLBcl-2 plus AxCANCre). Migration position of prestained molecular weight protein marker is shown on the left $(A-F) \cdot \operatorname{Ig} G(H)$ indicated by arrows in $C$ and $D$ shows the position of IgG heavy chain. their corresponding tag (HA and c-Myc) antibodies (Fig. 4B). Although da-MEK was expressed in the surviving hypoglossal neurons on postaxotomy day 7 , these cells clearly showed atrophic and degenerative changes. On the other hand, myr-Akt-positive motoneurons seemed to maintain a healthy profile with large cell bodies and long processes, even on postaxotomy day 12. Concomitantly, surviving neurons were counted on adjacent Nissl-stained sections (Fig. 4C). The surviving neurons were counted on both the injured and control sides, and the survival ratio was obtained (Fig. 4D). The expression of myr-Akt significantly protected neonate motoneurons from axotomy-induced neuronal death with an efficacy similar to that observed with Bcl-2-overexpressing ones, although the infection efficacy is partial. On the other hand, AxCAda-MEK failed to prevent axotomy-induced motoneuron death, although it was expressed strongly.

\section{Dominant negative Akt accelerated axotomy-induced neuronal death in neonates but not in adults}

Next, to gain more insight into significance of Akt, Akt-AAexpressing adenoviral vector was introduced into the same animal model as described above. Without nerve injury, we could not observe any decrease of cell number in Akt-AA-overexpressing animals, even $12 \mathrm{~d}$ after the viral infection (data not shown). However, in axotomized animals, the number of surviving cells was markedly decreased, especially in the early neuronal degenerative phase, which was not observed in LacZ-overexpressing animals (Fig. $5 A, B$ ). At $36 \mathrm{hr}$ after axotomy, Akt-AA-expressing neurons seem atrophic profiles (Fig. $5 A$ ). These results indicated that the reduction of Akt activity before axotomy might accelerate injury-induced neuronal death.

In addition, we also infected Akt-AA-expressing virus into injured adult motoneurons, which can normally survive, even after axotomy. The recombinant adenoviruses were infected from the cut end of the nerve immediately after nerve transection, because in adult rats this procedure seemed to produce a more efficient retrograde infection into the injured motoneurons than infection via the tongue (see below). Contrary to neonate motoneurons, overexpression of Akt-AA in injured adult motoneurons fail to decrease the number of surviving neurons, as well as LacZ virus-infected animals (Fig. 5C). This dominant negative experiment suggested that injured motoneurons in the adult rat 

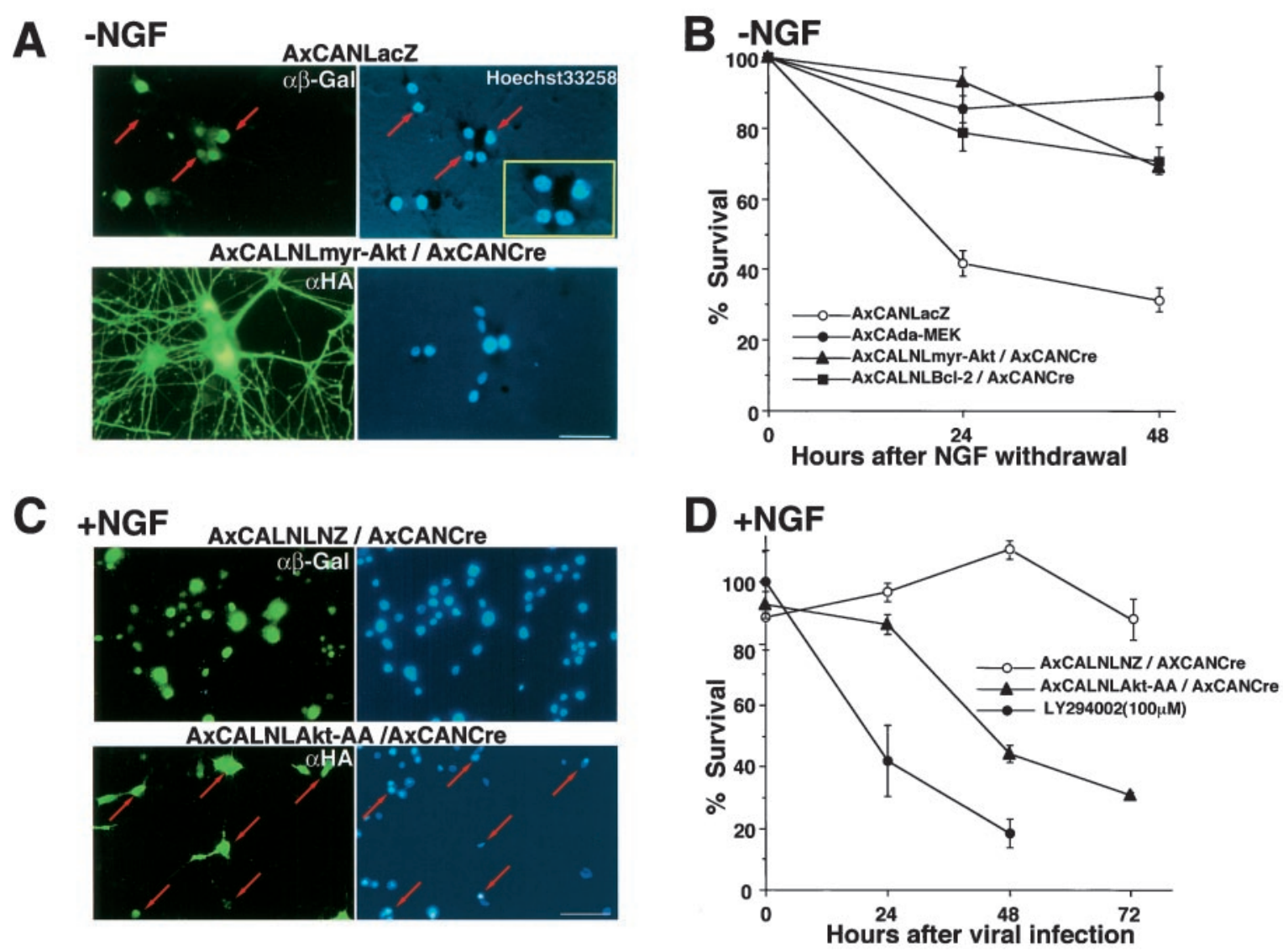

Figure 3. Effects of adenovirus-expressed myr-Akt and Akt-AA on neuronal survival in vitro. A, Photographs show PC12 cells infected with AxCANLacZ (top row) or AxCALNLmyr-Akt plus AxCANCre (bottom row) $18 \mathrm{hr}$ after NGF withdrawal. Infected cells were detected by anti- $\beta$-Gal antibody or anti-HA antibody followed by FITC-conjugated secondary antibody (left column). Right column shows Hoechst 33258 staining. The red arrows indicate cells that show condensed or fragmented chromatin. B, Viability of adenovirus-infected PC12 cells 24 and 48 hr after NGF withdrawal. Each $d o t$ represents the average of values from four different experiments. $C$, Photographs show PC12 cells infected with AxCANLacZ plus AxCANCre (top row) and AxCALNL Akt-AA plus AxCANCre (bottom row) under the presence of NGF. The infected cells were detected by the same antibody described in A (left column). Hoechst staining (right column) demonstrated that Akt-AA-expressing cells show apoptotic profiles (red arrows) as seen in NGF-deprived cells $(A$; red arrows). D, Viability of Akt-AA-expressed and LY294002-treated PC12 cells under the presence of NGF. Viability of LacZ-expressing PC12 cells is also examined as control. LY294002-treated cells show marked decrease of viability, and Akt-AA-expressed cells also demonstrated apparent decrease of viability. Scale bars: $A, C, 20 \mu \mathrm{m}$. Error bars indicate SEM in $B$ and $D$.

might be protected from neuronal death by not only Akt pathway but also another survival signaling pathway.

\section{Akt promotes neurite elongation in PC12 cells without NGF stimulation}

Interestingly, the present study using undifferentiated PC12 cells showed that adenovirus-expressed myr-Akt induced process elongation, even without NGF application (Fig. 6A). After the infection, the number of process bearing cells increased dramatically, and the efficacy was comparable with that of NGFstimulated $(50 \mathrm{ng} / \mathrm{ml})$ cells (Fig. 6B). Because in PC12 cells, Ras-ERK (Cowley et al., 1994), Rac-Jun N-terminal kinase (RacJNK) (Kita et al., 1998), and p38 MAP kinase (MAPK) pathway (Morooka and Nishida, 1998) were demonstrated to have some process elongation activity, we verified whether myr-Akt have any role in activation of any of these MAPK family members. Overexpression of myr-Akt in PC12 cells did not produce concomitant phosphorylation of any of the above kinases (Fig. 6C), which suggests the possibility that this process elongation occurs via a pathway other than the above mentioned ones.

\section{Akt promotes nerve regeneration in vivo}

Because neurite elongation was observed in myr-Akt-expressing cells in vitro, we expected that the axon elongation activity might be enhanced in myr-Akt-overexpressing axotomized motoneurons. To evaluate axon regeneration, we used the retrograde tracer FG, which, when injected into tongue, is uptaken from axon terminals, and retrogradely transported into the cell bodies (Hirota et al., 1996). FG was injected into both sides of tongue $2 \mathrm{~d}$ before the rats were killed to allow retrograde transport of the dye into the neuronal cell bodies. Animals were killed at 2, 3, and 4 weeks after nerve transection, and FG-positive cells were counted on both injured and control sides. The axon regenerating rate was evaluated by comparing FG-positive cell number in the intact and the injured hypoglossal nuclei. By two weeks after axotomy, $\sim 20 \%$ of myr-Akt-overexpressing motoneurons succeeded in regenerating into tongue, whereas the injured motoneurons overexpressing LacZ as control failed to do so during the same period (Fig. 7A). The number of successfully regenerating cells increased with the passage of time. The regeneration ratios in the myr-Akt-expressing neurons exceeded those in the LacZ- 
A

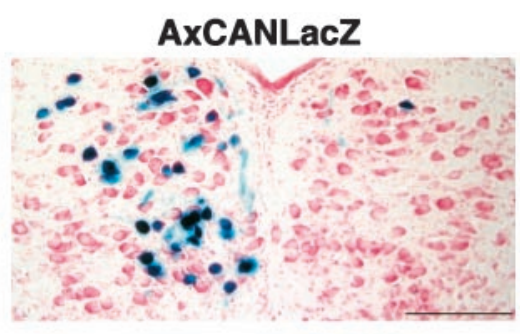

C

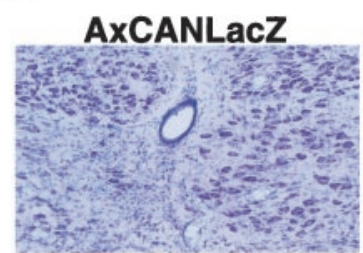

AxCALNLmyr-Akt IAXCANCre

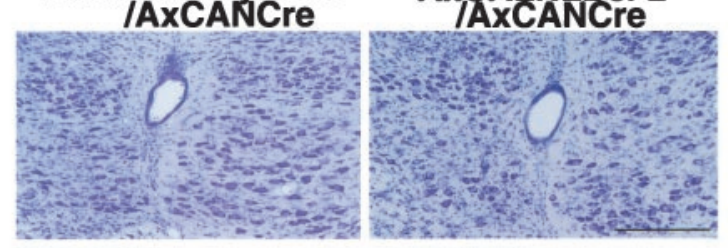

B

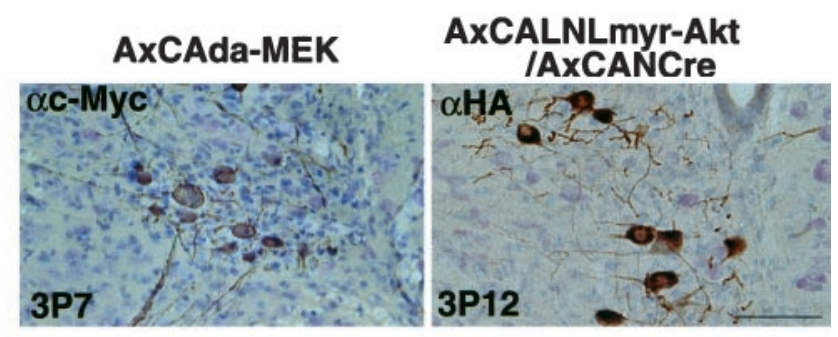

D

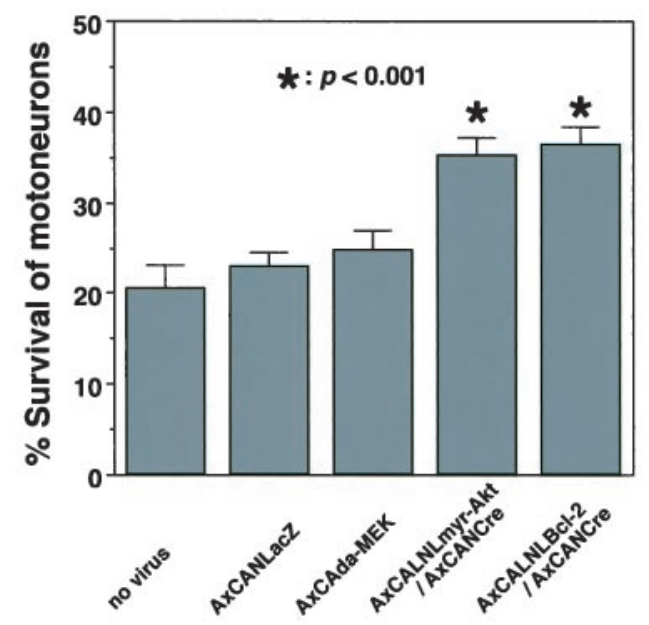

Figure 4. Expression of myr-Akt prevents axotomy-induced neuronal death in vivo. A, Ten days after injection of AxCANLacZ into the left side of the tongue, NLS-tagged $\beta$-Gal-positive staining is detected in the ipsilateral side of hypoglossal motoneurons. This indicates a typical rate of infection efficacy in the present study. $B$, Immunohistochemical detection of c-Myc-tagged da-MEK (left) and HA-tagged myr-Akt (right) in injured motoneurons (3P7 or 3P12). (After the viral infection, ipsilateral nerve was transected on third day after birth and observed on postoperative day 7 or 12 .) $C$, The survival activity by the infection of adenovirus expressing LacZ, da-MEK, myr-Akt, or Bcl-2. Sections are obtained $12 \mathrm{~d}$ after hypoglossal nerve transection and stained with thionin. $D$, The mean percentage of survival ratio of injured motoneurons $12 \mathrm{~d}$ after axotomy. For statistical analysis, at least 10 sections prepared from seven different animals were studied. ${ }^{*} p<0.001$, significant differences between survival ratio of injured motoneurons in each viral infected animals and that in animals without virus infection (ANOVA). Error bars indicate SEM. Scale bars: $A, C, 500 \mu \mathrm{m} ; B, 100 \mu \mathrm{m}$.

overexpressing ones by $>20 \%$ (Fig. $7 B$ ). This result clearly indicates that Akt overexpression has a significant effect in enhancing axonal regeneration in vivo.

\section{DISCUSSION}

In the present study, dual functions of Akt in neuronal survival and axonal regeneration were demonstrated in vivo. Both RasERK and PI3K-Akt pathways are known to have equivalent survival potentials in some cell lines; however, the present study clearly revealed that PI3K-Akt pathway is essential in vitro and significantly more vital in vivo, at least in the present experimental paradigm. Another novel finding that Akt has neurite elongation activity both in vitro and in vivo is also demonstrated. These in vivo results emphasize that Akt could be one of the major molecules for repair and regeneration of injured neurons.

\section{Activation of Akt in response to nerve injury}

Because many growth factors could rescue axotomy-induced neuronal death (for review, see Lindsay, 1995; Oppenheim, 1996), the most likely signals for the activation of Akt are the growth factors (or neurotrophins). In fact, various growth factors and their receptors together with their downstream signaling molecules are expressed in response to nerve injury. For instance, the expression of glial cell line-derived neurotrophic factor (GDNF), which has the most potent activity among various neurotrophins in terms of the survival-promoting activity (Henderson et al., 1994; Oppenheim et al., 1995; Yan et al., 1995), is enhanced in the denervated muscle and distal Schwann cells after axotomy (Trupp et al., 1997). In addition, GDNF receptors, both GFR $\alpha-1$ and c-Ret, are also upregulated in injured motoneurons in response to nerve injury (Trupp et al., 1997). Because both Ras-ERK and PI3K-Akt pathways are located downstream of these growth factor receptors, the activation of both pathways could be possible in vivo. Likewise, brain-derived neurotrophic factor, neurotrophin-3, neurotrophin-4/5, and some other factors seem to effect the injured motoneurons in a similar manner. Therefore, the synergistic stimuli by these factors might lead to activation of PI3K-Akt and/or Ras-ERK pathways after nerve injury. Both previous (Xia et al., 1995) and our present studies have demonstrated that activation of either of these two pathways did enhance cell survival in PC12 cells. However, the present animal study revealed that activation of Akt is more effective than MEK activation in survival of injured motoneurons. This apparent discrepancy between in vitro study using PC12 cells and our in vivo study reminds us of similar discrepancies that frequently exist within in vitro approaches themselves (Pettmann and Henderson, 1998). A recent study using primary sensory neurons showed that activation 
A

Figure 5. Effects of Akt pathway inhibition in injured motoneuron. A, Top, An immunohistochemical detection of adenovirus-expressed Akt-AA (detected by anti-HA antibody) in injured neonate motoneurons [3P1.5; the axotomy was done on the third day after birth, and the rats were killed $1.5 \mathrm{~d}(36 \mathrm{hr})$ after the operation]. Scale bar, $50 \mu \mathrm{m}$. Middle, Three days after axotomy, approximately half of motoneurons on the injured side (left) disappeared in Akt-AAexpressed animal (3P3; axotomized on the third day after birth and observed on postoperative day 3 ). Bottom, Many surviving neurons were observed in LacZ-expressing rat at the same time point (3P3). Scale bar, $200 \mu \mathrm{m}$. $B, C$, The mean percentage of surviving hypoglossal motoneurons after infection of either Akt-AA- or LacZ-expressing adenovirus in the neonate $(P 3)(B)$ and the adult $(C) . x$-Axis indicates days after axotomy. The statistical analysis was performed as described in the previous experiment. ${ }^{*} p<$ 0.01 , significant differences between survival ratio of injured motoneurons in Akt-AA-expressing animals and that in LacZ-expressing ones at each time point (Student's $t$ test). Error bars indicate SEM.

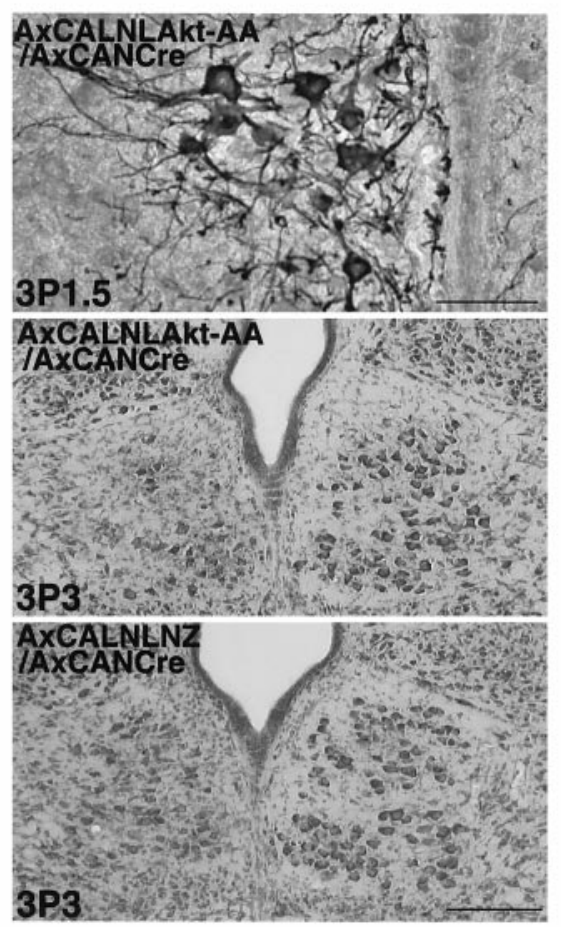

B P3

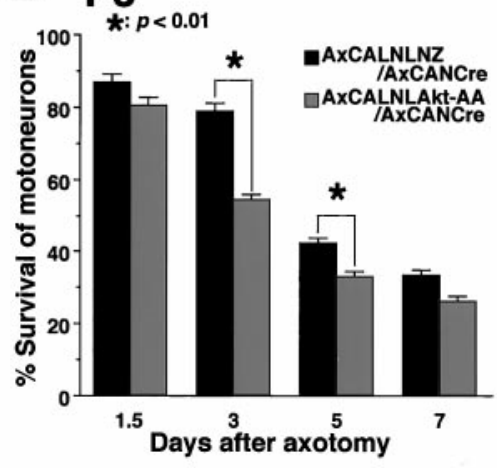

C Adult

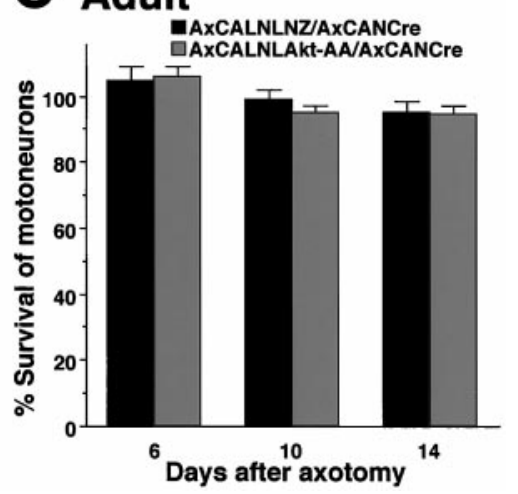

of MEK failed to promote neuronal survival (Klesse and Parada, 1998). In addition, studies using MEK inhibitor or the dominant negative mutant of MEK or ERK have demonstrated that RasERK pathway may be dispensable for neuronal survival induced by NGF both in primary sensory (Klesse and Parada, 1998) and sympathetic neurons (Creedon et al., 1996; Virdee and Tolkovsky, 1996). Furthermore, inhibition of PI3K or Akt activity did cause cell death in these cells (Yao and Cooper, 1995; Crowder and Freeman, 1998) or cerebellar granule cell culture (D’Mello et al., 1997; Dudek et al., 1997). These in vitro findings together with our present result strongly suggest that PI3K-Akt pathway is more potent for the survival of neuronal cells, at least in the axotomy-induced neuronal death paradigm.

The distinct expression profiles between Akt and ERK were clearly evident in our animal model. The present study demonstrated that Akt activation was enhanced in response to nerve injury in the adult (surviving neurons), whereas its activity was downregulated in injured neonate motoneurons (dying neurons). This suggests the importance of Akt activation in response to nerve injury for survival. In contrast, expression of ERK1 mRNA, which is a pivotal kinase in Ras-ERK pathway, was transiently upregulated in both adult and neonate (Kiryu et al., 1995a; and K. Mansur, unpublished data). The transient upregulation of ERK alone in the neonate seems not to promote neuronal survival. Although the role of ERK in axotomized motoneurons remains unclear, these opposite responses in axotomized neonate motoneurons suggest that these two downstream signaling cascades might not be subserving identical function, at least in our nerve injury model. Consequently, the failure of Akt activation in neonates in response to nerve injury may be one of the major reasons why axotomy induces neuronal death in neonate.

\section{How Akt prevents axotomy-induced neuronal death}

How activated Akt rescues injured motoneurons after axotomy is not yet clearly known, but previous studies have established that Akt phosphorylates death promoter BAD in culture cells (Datta et al., 1997; del Peso et al., 1997). Phosphorylated BAD binds with 14-3-3 in cytoplasm and thereby loses its capacity to interact with anti-apoptotic Bcl- $\mathrm{X}_{\mathrm{L}}$ (Zha et al., 1996). The freed Bcl- $\mathrm{X}_{\mathrm{L}}$ can thereby inhibit the downstream activation of caspase death cascade (Hu et al., 1998). Although BAD phosphorylation by Akt in surviving neurons has yet to be demonstrated in vivo, the activation of Bcl-2-related family members seems to be crucial for neuronal survival after axotomy. The transgenic motoneurons

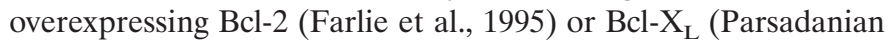
et al., 1998) prevented axotomy-induced cell death, which we also confirmed by our present study using Bcl-2-expressing adenovirus. Similar survival activity in axotomized neonate motoneurons was also observed in pro-apoptotic BAX-deficient mice (Deckwerth et al., 1996). In the present study, the survival activity of Akt both in vitro and in vivo is similar to that of Bcl-2. Thus, one of the most likely targets of Akt seems to be the Bcl-2-related anti-apoptotic molecules, which prevent neuronal death via BAD phosphorylation. One recent report showed that Akt can phosphorylate caspase-9 and inhibit its protease activity in vitro (Cardone et al., 1998) and thereby can block its downstream cascade. This might be an alternative mechanism of Akt for the prevention of cell death. Some animal experiments demonstrated that expression and activity of caspase-3, a substrate of caspase-9, were enhanced in the dying neurons after experimental brain trauma, ischemia, or transection of optic nerve, and a caspase- 3 inhibitor significantly reduced such induced neuronal cell death (Yakovlev et al., 1997; Chen et al., 1998; Kermer et al., 1998), suggesting that 
A

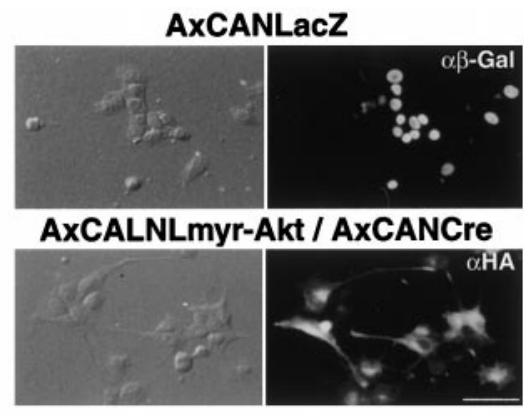

B
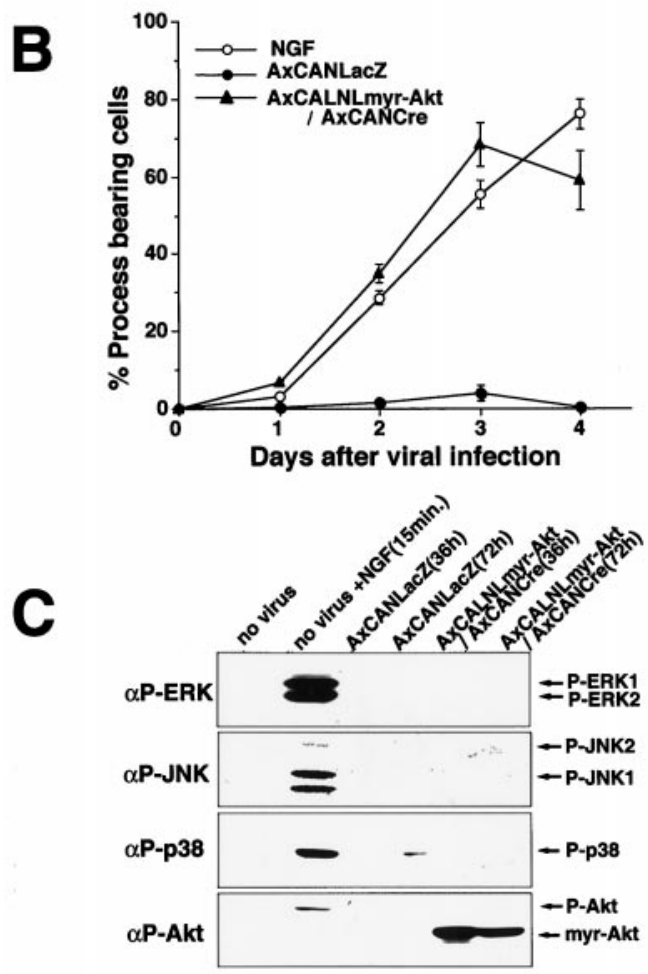

Figure 6. Expression of myr-Akt induces process elongation in $\mathrm{PC} 12$ cells. $A$, PC12 cells infected with AxCANLacZ show no significant change in cell shapes, but the infection with AxCALNLmyr-Akt plus AxCANCre caused clear process elongation $2 \mathrm{~d}$ after the infection. Infected cells were immunodetected by using anti- $\beta$-Gal antibody or anti-HA antibody, respectively (right column). Scale bar, $20 \mu \mathrm{m}$. B. Time course of percentages of process bearing cells after the infection of each recombinant virus or application of NGF $(50 \mathrm{ng} / \mathrm{ml})$. $C$, Detection of activated MAPK family members (MAPKs, ERKs, JNKs, and p38 MAPK) by antibodies specific to phosphorylated MAPKs $(\alpha P-E R K, \alpha P-J N K, \alpha P-p 38)$. In PC12 cells, phosphorylation of MAPKs were not observed 36 and $72 \mathrm{hr}$ after the infection of AxCALNLmyr-Akt plus AxCANCre, whereas all of MAPKs were phosphorylated $15 \mathrm{~min}$ after NGF stimulation $(50 \mathrm{ng} / \mathrm{ml})$.

activation of caspase-9-caspase-3 cascade might be induced after various kinds of neuronal injury, as well as in the developing nervous system during programmed cell death (Kuida et al., 1996, 1998). More recent study demonstrated Akt also phosphorylates FKHRL1, one of the Forkhead transcription factor family members, and transcriptionally regulates Fas-dependent apoptosis in cerebellar granule neurons. After phosphorylation of FKHRL1, it translocates to cytoplasm from nucleus and also binds to 14-3-3. As a result, this transcription factor loses its death-promoting activity, which induces Fas ligand expression and apoptosis (Brunet et al., 1999). Although it is not clear whether Fas-dependent death system is involved in injury-induced motoneuron death in the neonate, other similar transcriptional regulation by Akt is likely to be involved in the survival mechanism.

Another possible effect of activated Akt might be an enhancement of cell metabolism to maintain the integrity of injured neurons. Among its many possible functions, Akt activates p70 ${ }^{\mathrm{S} 6}$ kinase, which enhances protein synthesis (Burgering and Coffer, 1995; Kohn et al., 1998). It also promotes glucose uptake by translocating GLUT4 glucose transporter to the cell membrane (Kohn et al., 1996b, 1998). By effective multiple processes, Akt might activate glucose metabolism to provide ample energy during critical period, and additionally by promoting protein synthesis it supplies essential molecules that are necessary for survival.

\section{Possible Akt-independent survival pathway in injured adult motoneurons}

In addition to survival activity of dominant active Akt in injured motoneurons in the neonate, dominant negative Akt hastened axotomy-induced neuronal death in the neonate. These dominant active and negative studies clearly indicate that injury-induced neuronal death observed in the neonate is attributable to failure of activation of Akt. On the other hand, the present dominant negative Akt experiment in the adult rat suggests that another Akt-independent survival signaling pathway is likely to exist in matured motoneurons. At least in vitro, a number of signaling molecules were identified as potent survival-promoting factors in addition to Akt. Of these molecules, PKA seems to have a similar activity to Akt. PKA could also phosphorylate BAD (at a different phosphorylated site) in IL3-dependent hematopoietic cells and thereby results in promoting cell survival (Harada et al., 1999). In fact, elevation of cAMP levels could inhibit apoptosis, which is independent of growth factors in several neuronal cultures, including motor systems (Rydell and Greene, 1988; Creedon et al., 1996; Hanson et al., 1998). Although it is unclear whether the CAMP-PKA system is an alternative mechanism for adult motoneurons to prevent injury-induced cell death, coordinate activation of such survival mediators in addition to Akt might be crucial to protect neurons from axotomy-induced neuronal death in the adult.

\section{Possible mechanism underlying neurite elongation by Akt}

It is well known that Ras-ERK activation is necessary and sufficient for neurite elongation in NGF-stimulated PC12 cells (Kaplan and Miller, 1997), but here we demonstrated that activation of Akt induces a similar phenomenon not only in PC12 cells but also in vivo. We examined the possibility whether Akt activated MAP kinase family members (ERKs, JNKs, and p38) via some unknown pathways for the neurite elongation, but we could not detect any enhancement of these kinase activities in myr-Akt-overexpressing cells. Thus, the present study suggests a possible other Akt downstream pathway for neurite elongation. A previous study implicated PI3K in maintenance and neurite extension in PC12 cells (Kimura et al., 1994). Another study demonstrated that primary dopaminergic neuron cultures required activation of PI3K for its GDNF-stimulated morphological differentiation (Pong et al., 1998). Moreover, in primary sensory or sympathetic neuronal cultures, blockade of ERK activity failed to inhibit neurite outgrowth (Klinz et al., 1996; Klesse and Parada, 1998). These culture studies suggest that PI3K activity leads to neuronal differentiation, at least in some primary neurons, and the present study further suggested that these morphological 
A

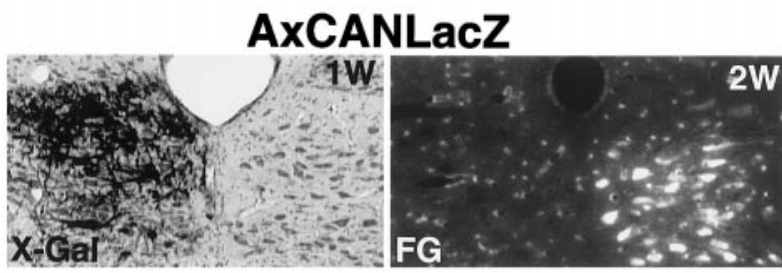

AxCALNLmyr-Akt / AxCANCre

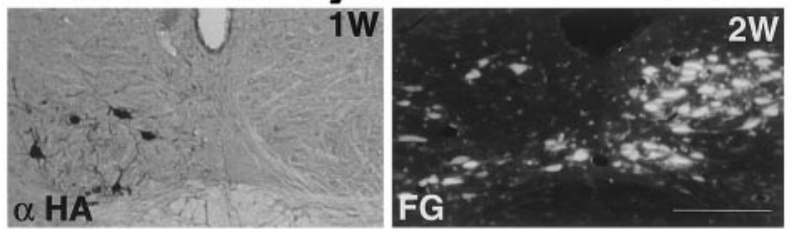

B

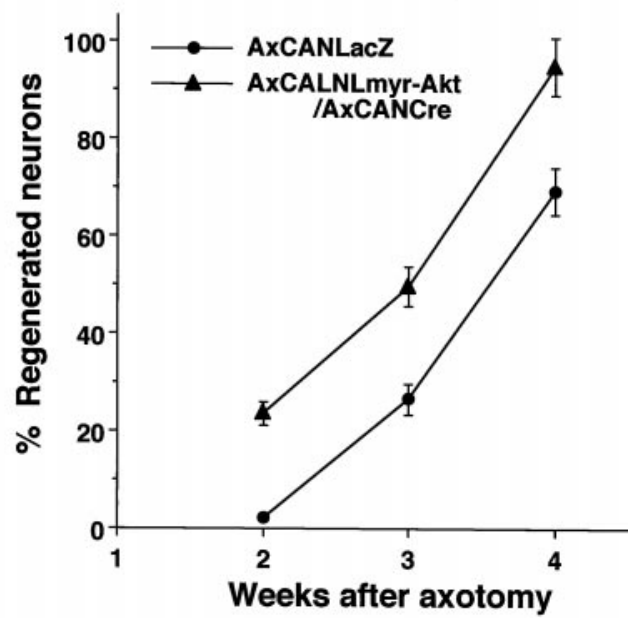

Figure 7. Expression of myr-Akt accelerates nerve regeneration in adult rats. A, Top row, AxCANLacZ-infected motoneurons (the expression was examined by X-Gal staining 1 week after infection; top left) show no FG-positive (regenerated) neurons on the injured side at 2 weeks after injury (top right). Bottom row, In contrast, AxCALNLmyr-Akt plus AxCANCre-infected motoneurons (the expression was detected by anti-HA antibody 1 week after infection; bottom left) show moderate number of FG-positive (regenerated) cells in injured nucleus at 2 weeks after axotomy (bottom right). Scale bar, $0.8 \mathrm{~mm} . B$ shows time course of nerve regeneration rate after axotomy in rats infected with AxCANLacZ or AxCALNLmyr-Akt plus AxCANCre. The regeneration rate was assessed by calculating the percent ratio of the number of FG-stained cell bodies in the operated side to those in control side. Three animals were examined at each time point. Error bars indicate SEM.

changes are likely to be induced via Akt activation. Although how Akt induces neurite formation in PC12 cells is not clear, cAMP response element-binding protein (CREB) (Du and Montminy, 1998) and GSK-3 (glycogen synthase kinase-3) (Cross et al., 1995) may be other possible targets of Akt. An implication of CREBATF1 heterodimer in cAMP-induced neurite elongation in PC12D cells has been demonstrated (Shimomura et al., 1998). Before addressing the issue of Akt-induced axonal regeneration in vivo, the details of Akt-induced neurite elongation in vitro should receive priority.

\section{Potentials for recombinant Akt gene delivery in neurological disorders}

The pervious studies showed motoneuron death caused by nerve injury can be prevented by neurotrophic (growth) factors. This fact has generated a great deal of interest in the therapeutic potentials of neurotrophic factors in clinical neurodegenerative conditions. However, there are numerous growth factors that appears to promote motoneuronal survival, and probably most motoneurons require multiple factors from diverse sources for optimal survival (Oppenheim, 1996). Attempts to obtain the most optimal composition of cocktails of growth factors have been made, and it seems that such cocktails provide a significant synergistic effect (Vejsada et al., 1995; Gravel et al., 1997). Most of these growth factor mediated-signals are conveyed via PI3KAkt and/or Ras-ERK pathways, and our present study clearly demonstrated that PI3K-Akt pathway does have a major role in preventing injury-induced neuronal death. In this respect, we would like to conclude that Akt, being at a convergent point of growth factor receptor signaling cascades for neuronal survival and regeneration, might be the most effective target in providing both neuronal survival and nerve regeneration. To activate this target in vivo, the use of recombinant adenovirus was found to be highly effective in our present study. Therefore, the present approach using a specific signaling molecule, such as Akt, may provide a potential therapeutic intervention aimed at functional recovery in a number of clinical conditions, such as brain trauma, ischemia, or neurodegenerative diseases, such as amyotrophic lateral sclerosis and Parkinson's disease.

\section{REFERENCES}

Akli S, Caillaud C, Vigne E, Stratford-Perricaudet LD, Poenaru L, Perricaudet M, Kahn A, Peschanski MR (1993) Transfer of a foreign gene into the brain using adenovirus vectors. Nat Genet 3:224-228.

Batistatou A, Merry DE, Korsmeyer SJ, Greene LA (1993) Bcl-2 affects survival but not neuronal differentiation of PC12 cells. J Neurosci 13:4422-4428.

Bergmann A, Agapite J, McCall K, Steller H (1998) The Drosophila gene hid is a direct molecular target of Ras-dependent survival signaling. Cell 95:331-341.

Brunet A, Bonni A, Zigmond MJ, Lin MZ, Juo P, Hu LS, Anderson MJ, Arden KC, Blenis J, Greenberg ME (1999) Akt promotes cell survival by phosphorylating and inhibiting a Forkhead transcription factor. Cell 96:857-868.

Burgering BM, Coffer PJ (1995) Protein kinase B (c-Akt) in phosphatidylinositol-3-OH kinase signal transduction. Nature 376:599-602.

Cardone MH, Roy N, Stennicke HR, Salvesen GS, Franke TF, Stanbridge E, Frisch S, Reed JC (1998) Regulation of cell death protease caspase- 9 by phosphorylation. Science $282: 1318-1321$.

Chen J, Nagayama T, Jin K, Stetler RA, Zhu RL, Graham SH, Simon RP (1998) Induction of caspase-3-like protease may mediate delayed neuronal death in the hippocampus after transient cerebral ischemia. J Neurosci 18:4914-4928.

Cowley S, Paterson H, Kemp P, Marshall CJ (1994) Activation of MAP kinase kinase is necessary and sufficient for PC12 differentiation and for transformation of NIH 3T3 cells. Cell 77:841-852.

Creedon DJ, Johnson EM, Lawrence JC (1996) Mitogen-activated protein kinase-independent pathways mediate the effects of nerve growth factor and cAMP on neuronal survival. J Biol Chem 271:20713-20718.

Cross DA, Alessi DR, Cohen P, Andjelkovich M, Hemmings BA (1995) Inhibition of glycogen synthase kinase- 3 by insulin mediated by protein kinase B. Nature 378:785-789.

Crowder RJ, Freeman RS (1998) Phosphatidylinositol 3-kinase and Akt protein kinase are necessary and sufficient for the survival of nerve growth factor-dependent sympathetic neurons. J Neurosci 18:2933-2943.

D’Mello SR, Borodezt K, Soltoff SP (1997) Insulin-like growth factor 
and potassium depolarization maintain neuronal survival by distinct pathways: possible involvement of PI 3- kinase in IGF-1 signaling. J Neurosci 17:1548-1560.

Datta SR, Dudek H, Tao X, Masters S, Fu H, Gotoh Y, Greenberg ME (1997) Akt phosphorylation of BAD couples survival signals to the cell- intrinsic death machinery. Cell 91:231-241.

Davidson BL, Allen ED, Kozarsky KF, Wilson JM, Roessler BJ (1993) A model system for in vivo gene transfer into the central nervous system using an adenoviral vector. Nat Genet 3:219-223.

Deckwerth TL, Elliott JL, Knudson CM, Johnson Jr EM, Snider WD, Korsmeyer SJ (1996) BAX is required for neuronal death after trophic factor deprivation and during development. Neuron 17:401-411.

del Peso L, Gonzalez-Garcia M, Page C, Herrera R, Núñez G (1997) Interleukin-3-induced phosphorylation of BAD through the protein kinase Akt. Science 278:687-689.

Downward J (1998) Lipid-regulated kinases: some common themes at last. Science 279:673-674.

Du K, Montminy M (1998) CREB is a regulatory target for the protein kinase Akt/PKB. J Biol Chem 273:32377-32379.

Dudek H, Datta SR, Franke TF, Birnbaum MJ, Yao R, Cooper GM, Segal RA, Kaplan DR, Greenberg ME (1997) Regulation of neuronal survival by the serine-threonine protein kinase Akt. Science 275:661-665.

Farlie PG, Dringen R, Rees SM, Kannourakis G, Bernard O (1995) bcl-2 transgene expression can protect neurons against developmental and induced cell death. Proc Natl Acad Sci USA 92:4397-4401.

Franke TF, Yang SI, Chan TO, Datta K, Kazlauskas A, Morrison DK, Kaplan DR, Tsichlis PN (1995) The protein kinase encoded by the Akt proto-oncogene is a target of the PDGF-activated phosphatidylinositol 3-kinase. Cell 81:727-736.

Fukuda M, Gotoh Y, Nishida E (1997) Interaction of MAP kinase with MAP kinase kinase: its possible role in the control of nucleocytoplasmic transport of MAP kinase. EMBO J 16:1901-1908.

Gravel C, Gotz R, Lorrain A, Sendtner M (1997) Adenoviral gene transfer of ciliary neurotrophic factor and brain-derived neurotrophic factor leads to long-term survival of axotomized motor neurons. Nat Med 3:765-770.

Hamburger V (1934) The effects of wing bud extirpation on the development of the central nervous system in chick embryos. J Exp Zool 68:449-494.

Hanson Jr MG, Shen S, Wiemelt AP, McMorris FA, Barres BA (1998) Cyclic AMP elevation is sufficient to promote the survival of spinal motor neurons in vitro. J Neurosci 18:7361-7371.

Harada H, Becknell B, Wilm M, Mann M, Huang LJ, Taylor SS, Scott JD, Korsmeyer SJ (1999) Phosphorylation and inactivation of BAD by mitochondria-anchored protein kinase A. Mol Cell 3:413-422.

Henderson CE, Phillips HS, Pollock RA, Davies AM, Lemeulle C, Armanini M, Simmons L, Moffet B, Vandlen RA, Simpson LC, Moffet B, Vandlen RA, Koliatsos VE, Rosenthal A (1994) GDNF: a potent survival factor for motoneurons present in peripheral nerve and muscle. Science 266:1062-1064.

Hirota H, Kiyama H, Kishimoto T, Taga T (1996) Accelerated nerve regeneration in mice by upregulated expression of interleukin (IL) 6 and IL-6 receptor after trauma. J Exp Med 183:2627-2634.

Hu Y, Benedict MA, Wu D, Inohara N, Núñez G (1998) Bcl-XL interacts with Apaf-1 and inhibits Apaf-1-dependent caspase-9 activation. Proc Natl Acad Sci USA 95:4386-4391.

Ishiyama M, Tominaga H, Shiga M, Sasamoto K, Ohkura Y, Ueno K (1996) A combined assay of cell viability and in vitro cytotoxicity with a highly water-soluble tetrazolium salt, neutral red and crystal violet. Biol Pharm Bull 19:1518-1520.

Ito Y, Sakagami H, Kondo H (1996) Enhanced gene expression for phosphatidylinositol 3-kinase in the hypoglossal motoneurons following axonal crush. Mol Brain Res 37:329-332.

Kanegae Y, Makimura M, Saito I (1994) A simple and efficient method for purification of infectious recombinant adenovirus. Jpn J Med Sci Biol 47:157-166.

Kanegae Y, Lee G, Sato Y, Tanaka M, Nakai M, Sakaki T, Sugano S, Saito I (1995) Efficient gene activation in mammalian cells by using recombinant adenovirus expressing site-specific Cre recombinase. Nucleic Acids Res 23:3816-3821.

Kaplan DR, Miller FD (1997) Signal transduction by the neurotrophin receptors. Curr Opin Cell Biol 9:213-221.

Kermer P, Klocker N, Labes M, Bahr M (1998) Inhibition of CPP32-like proteases rescues axotomized retinal ganglion cells from secondary cell death in vivo. J Neurosci 18:4656-4662.

Kimura K, Hattori S, Kabuyama Y, Shizawa Y, Takayanagi J, Nakamura S, Toki S, Matsuda Y, Onodera K, Fukui Y (1994) Neurite outgrowth of PC12 cells is suppressed by wortmannin, a specific inhibitor of phosphatidylinositol 3-kinase. J Biol Chem 269:18961-18967.

Kiryu S, Morita N, Ohno K, Maeno H, Kiyama H (1995a) Regulation of mRNA expression involved in Ras and PKA signal pathways during rat hypoglossal nerve regeneration. Mol Brain Res 29:147-156.

Kiryu S, Yao GL, Morita N, Kato H, Kiyama H (1995b) Nerve injury enhances rat neuronal glutamate transporter expression: identification by differential display PCR. J Neurosci 15:7872-7878.

Kita Y, Kimura KD, Kobayashi M, Ihara S, Kaibuchi K, Kuroda S, Ui M, Iba H, Konishi H, Kikkawa U, Nagata S, Fukui Y (1998) Microinjection of activated phosphatidylinositol-3 kinase induces process outgrowth in rat PC12 cells through the Rac-JNK signal transduction pathway. J Cell Sci 111:907-915.

Kitamura T, Ogawa W, Sakaue H, Hino Y, Kuroda S, Takata M, Matsumoto M, Maeda T, Konishi H, Kikkawa U, Kasuga M (1998) Requirement for activation of the serine-threonine kinase Akt (protein kinase B) in insulin stimulation of protein synthesis but not of glucose transport. Mol Cell Biol 18:3708-3717.

Klesse LJ, Parada LF (1998) p21 ras and phosphatidylinositol-3 kinase are required for survival of wild-type and NF1 mutant sensory neurons. J Neurosci 18:10420-10428.

Klinz FJ, Wolff P, Heumann R (1996) Nerve growth factor-stimulated mitogen-activated protein kinase activity is not necessary for neurite outgrowth of chick dorsal root ganglion sensory and sympathetic neurons. J Neurosci Res 46:720-726.

Kohn AD, Takeuchi F, Roth RA (1996a) Akt, a pleckstrin homology domain containing kinase, is activated primarily by phosphorylation. J Biol Chem 271:21920-21926.

Kohn AD, Summers SA, Birnbaum MJ, Roth RA (1996b) Expression of a constitutively active Akt Ser/Thr kinase in 3T3-L1 adipocytes stimulates glucose uptake and glucose transporter 4 translocation. J Biol Chem 271:31372-31378.

Kohn AD, Barthel A, Kovacina KS, Boge A, Wallach B, Summers SA, Birnbaum MJ, Scott PH, Lawrence Jr JC, Roth RA (1998) Construction and characterization of a conditionally active version of the serine/ threonine kinase Akt. J Biol Chem 273:11937-11943.

Konishi H, Shinomura T, Kuroda S, Ono Y, Kikkawa U (1994) Molecular cloning of rat RAC protein kinase alpha and beta and their association with protein kinase $\mathrm{C}$ zeta. Biochem Biophys Res Commun 205:817-825.

Kuida K, Zheng TS, Na S, Kuan C, Yang D, Karasuyama H, Rakic P, Flavell RA (1996) Decreased apoptosis in the brain and premature lethality in CPP32- deficient mice. Nature 384:368-372.

Kuida K, Haydar TF, Kuan CY, Gu Y, Taya C, Karasuyama H, Su MS, Rakic P, Flavell RA (1998) Reduced apoptosis and cytochrome c-mediated caspase activation in mice lacking caspase 9. Cell 94:325-337.

Kurada P, White K (1998) Ras promotes cell survival in Drosophila by downregulating hid expression. Cell 95:319-329.

Lindsay RM (1995) Neuron saving schemes. Nature 373:289-290.

Mansour SJ, Matten WT, Hermann AS, Candia JM, Rong S, Fukasawa K, Vande Woude GF, Ahn NG (1994) Transformation of mammalian cells by constitutively active MAP kinase kinase. Science 265:966-970.

Miyake S, Makimura M, Kanegae Y, Harada S, Sato Y, Takamori K, Tokuda C, Saito I (1996) Efficient generation of recombinant adenoviruses using adenovirus DNA-terminal protein complex and a cosmid bearing the full-length virus genome. Proc Natl Acad Sci USA 93:1320-1324.

Morita N, Kiryu S, Kiyama H (1996) p53-independent cyclin G expression in a group of mature neurons and its enhanced expression during nerve regeneration. J Neurosci 16:5961-5966.

Morooka T, Nishida E (1998) Requirement of p38 mitogen-activated protein kinase for neuronal differentiation in PC12 cells. J Biol Chem 273:24285-24288.

Namikawa K, Su Q, Kiryu-Seo S, Kiyama H (1998) Enhanced expression of 14-3-3 family members in injured motoneurons. Mol Brain Res 55:315-320.

Niwa H, Yamamura K, Miyazaki J (1991) Efficient selection for highexpression transfectants with a novel eukaryotic vector. Gene 108:193-199. 
Oppenheim RW (1996) Neurotrophic survival molecules for motoneurons: an embarrassment of riches. Neuron 17:195-197.

Oppenheim RW, Houenou LJ, Johnson JE, Lin LF, Li L, Lo AC, Newsome AL, Prevette DM, Wang S (1995) Developing motor neurons rescued from programmed and axotomy-induced cell death by GDNF. Nature 373:344-346.

Owada Y, Utsunomiya A, Yoshimoto T, Kondo H (1997) Expression of mRNA for Akt, serine-threonine protein kinase, in the brain during development and its transient enhancement following axotomy of hypoglossal nerve. J Mol Neurosci 9:27-33.

Parsadanian AS, Cheng Y, Keller-Peck CR, Holtzman DM, Snider WD (1998) Bcl-xL is an antiapoptotic regulator for postnatal CNS neurons J Neurosci 18:1009-1019.

Persson H, Ibáñez CF (1993) Role and expression of neurotrophins and the trk family of tyrosine kinase receptors in neural growth and rescue after injury. Curr Opin Neurol Neurosurg 6:11-18.

Pettmann B, Henderson CE (1998) Neuronal cell death. Neuron 20: 633-647.

Philpott KL, McCarthy MJ, Klippel A, Rubin LL (1997) Activated phosphatidylinositol 3-kinase and Akt kinase promote survival of superior cervical neurons. J Cell Biol 139:809-815.

Pong K, Xu RY, Baron WF, Louis JC, Beck KD (1998) Inhibition of phosphatidylinositol 3-kinase activity blocks cellular differentiation mediated by glial cell line-derived neurotrophic factor in dopaminergic neurons. J Neurochem 71:1912-1919.

Resh MD (1994) Myristylation and palmitylation of Src family members: the fats of the matter. Cell 76:411-413.

Romanes GJ (1946) Motor localization and the effects of nerve injury on the ventral horn cells of the spinal cord. J Anat 80:117-131.

Rydell RE, Greene LA (1988) cAMP analogs promote survival and neurite outgrowth in cultures of rat sympathetic and sensory neurons independently of NGF. Proc Natl Acad Sci USA 85:1257-1261.

Sato Y, Tanaka K, Lee G, Kanegae Y, Sakai Y, Kaneko S, Nakabayashi H, Tamaoki T, Saito I (1998a) Enhanced and specific gene expression via tissue-specific production of Cre recombinase using adenovirus vector. Biochem Biophys Res Commun 244:455-462.

Sato N, Wang S, Li L, Okabe K, Hashimoto M, Yaginuma H, Mikoshiba K, Uchiyama Y, Uetsuki T, Yoshikawa K, Milligan CE, Oppenheim RN (1998b) A novel strategy for introducing exogenous bcl-2 into neuronal cells: the Cre/loxP system-mediated activation of bcl-2 for preventing programmed cell death using recombinant adenoviruses. Mol Cell Neurosci 12:65-78.

Shimomura A, Okamoto Y, Hirata Y, Kobayashi M, Kawakami K, Kiuchi K, Wakabayashi T, Hagiwara M (1998) Dominant negative ATF1 blocks cyclic AMP-induced neurite outgrowth in PC12D cells. J Neurochem 70:1029-1034.

Snider WD (1994) Functions of the neurotrophins during nervous system development: what the knockouts are teaching us. Cell 77:627-638.
Snider WD, Elliott JL, Yan Q (1992) Axotomy-induced neuronal death during development. J Neurobiol 23:1231-1246.

Su QN, Namikawa K, Toki H, Kiyama H (1997) Differential display reveals transcriptional up-regulation of the motor molecules for both anterograde and retrograde axonal transport during nerve regeneration. Eur J Neurosci 9:1542-1547.

Tanabe K, Kiryu-Seo S, Nakamura T, Mori N, Tsujino H, Ochi T, Kiyama H (1998) Alternative expression of Shc family members in nerve-injured motoneurons. Mol Brain Res 53:291-296.

Terashima T, Miwa A, Kanegae Y, Saito I, Okado H (1997) Retrograde and anterograde labeling of cerebellar afferent projection by the injection of recombinant adenoviral vectors into the mouse cerebellar cortex. Anat Embryol 196:363-382.

Toki H, Namikawa K, Su Q, Kiryu-Seo S, Sato K, Kiyama H (1998) Enhancement of extracellular glutamate scavenge system in injured motoneurons. J Neurochem 71:913-919.

Trupp M, Belluardo N, Funakoshi H, Ibáñez CF (1997) Complementary and overlapping expression of glial cell line-derived neurotrophic factor (GDNF), c-ret proto-oncogene, and GDNF receptor- $\alpha$ indicates multiple mechanisms of trophic actions in the adult rat CNS. J Neurosci 17:3554-3567.

Vejsada R, Sagot Y, Kato AC (1995) Quantitative comparison of the transient rescue effects of neurotrophic factors on axotomized motoneurons in vivo. Eur J Neurosci 7:108-115.

Virdee K, Tolkovsky AM (1996) Inhibition of p42 and p44 mitogenactivated protein kinase activity by PD98059 does not suppress nerve growth factor-induced survival of sympathetic neurones. J Neurochem 67:1801-1805.

Xia Z, Dickens M, Raingeaud J, Davis RJ, Greenberg ME (1995) Opposing effects of ERK and JNK-p38 MAP kinases on apoptosis. Science 270:1326-1331.

Yakovlev AG, Knoblach SM, Fan L, Fox GB, Goodnight R, Faden AI (1997) Activation of CPP32-like caspases contributes to neuronal apoptosis and neurological dysfunction after traumatic brain injury. J Neurosci 17:7415-7424.

Yan Q, Matheson C, Lopez OT (1995) In vivo neurotrophic effects of GDNF on neonatal and adult facial motor neurons. Nature 373:341-344.

Yano S, Tokumitsu H, Soderling TR (1998) Calcium promotes cell survival through CaM-K kinase activation of the protein-kinase-B pathway. Nature 396:584-587.

Yao R, Cooper GM (1995) Requirement for phosphatidylinositol-3 kinase in the prevention of apoptosis by nerve growth factor. Science 267:2003-2006

Zha J, Harada H, Yang E, Jockel J, Korsmeyer SJ (1996) Serine phosphorylation of death agonist BAD in response to survival factor results in binding to 14-3-3 not BCL-X(L). Cell 87:619-628. 